\title{
KEMAMPUAN BERPIKIR KRITIS SISWA SMP MELALUI PENDEKATAN PENDIDIKAN MATEMATIKA REALISTIK INDONESIA
}

\author{
Thasyia Indira ${ }^{1}$, Somakim ${ }^{2}$, Ely Susanti ${ }^{3}$ \\ ${ }^{1}$ Alumni Mahasiswa Pendidikan MatematikaUniversitas Sriwijaya \\ ${ }^{2,3}$ Dosen FKIP Universitas Sriwijaya \\ E-mail: thasyiaaa@gmail.com
}

\begin{abstract}
ABSTRAK
Penelitian ini bertujuan untuk mengetahui kemampuan berpikir kritis siswa kelas IX dengan penerapan pendekatan PMRI pada materi barisan dan deret. Penelitian ini merupakan jenis penelitian deskriptif dengan subjek penelitian siswa kelas IX.2 SMP Negeri 1 Indralaya Selatan yang berjumlah 25 orang. Proses pembelajaran berlangsung sesuai dengan karakteristik dan prinsip PMRI. Teknik pengumpulan data yang digunakan adalah tes tertulis yang terdiri dari dua soal, wawancara, dan observasi untuk memperoleh data tambahan. Berdasarkan hasil penelitian diperoleh hasil bahwa kemampuan berpikir kritis siswa dengan penerapan PMRI di kelas IX.2 SMP Negeri 1 Indralaya Selatan memiliki kemampuan berpikir kritis cukup baik dengan rincian sebagai berikut: presentase siswa yang memiliki kemampuan berpikir kritis berkategori sangat baik sebanyak 24\%, siswa yang memiliki kemampuan berpikir kritis berkategori baik sebanyak 28\%, siswa yang memiliki kemampuan berpikir kritis berkategori cukup sebanyak 12\%, dan siswa yang memiliki kemampuan berpikir kritis berkategori kurang sebanyak 36\%. Indikator interpretasi memiliki kemunculan tertinggi yaitu sebesar 92,67\%. Kemudian kemunculan pada indikator analisis sebesar $82 \%$, kemunculan indikator evaluasi sebesar 45\%. Dan indikator dengan presentse kemunculan terendah adalah inference yaitu sebesar 44,67\%.
\end{abstract}

Kata Kunci: Kemampuan berpikir kritis, PMRI

\section{PENDAHULUAN}

Pembelajaran matematika memiliki peranan untuk membantu siswa membuat keputusan dan kesimpulan atas dasar pemikiran secara logis, rasional, kritis, cermat, jujur, efisien, dan efektif agar sanggup menghadapi tantangan di dunia yang selalu berkembang (Somakim,2011). Sejalan dengan hal tersebut maka kemampuan berpikir kritis sangat diperlukan siswa. Berpikir kritis didefinisikan sebagai berpikir secara beralasan dan reflektif dengan menekankan pada pembuatan keputusan tentang apa yang harus dipercayai atau dilakukan (Fatmawati, Mardiana, \& Triyanto,2014).

Kemampuan berpikir kritis merupakan proses kognitif untuk memperoleh pengetahuan. Berdasarkan Fithriyah, dkk (2016) terdapat lima indikator kemampuan berpikir kritis, yaitu : Interpretation, Analysis, Evaluation, Inference, dan Explanation. Kemampuan berpikir kritis seyogyanya dikembangkan sejak usia dini agar siswa memiliki keterampilan intelektual tingkat tinggi, maka sejak usia dini itulah harus dilatih keterampilan kritis, kreativitas, memecahkan masalah, dan membuat keputusan (Muhfahroyin, 2009). Pentingnya kemampuan berpikir kritis juga diungkapkan oleh Peter 
"Student who are able to think critically are able to solve problem effectively" yakni agar dapat bersaing dalam dunia kerja dan pribadi, siswa harus memiliki kemampuan pemecahan masalah dan harus bisa berpikir dengan kritis (Hanifah, 2013).

Faktanya, berdasarkan hasil PISA 2015 walaupun posisi siswa Indonesia mengalami peningkatan dari PISA 2012 sebelumnya, namun secara umum masih terdapat 42,3\% siswa Indonesia yang posisinya berada di bawah level 2 yang berarti siswa Indonesia masih sangat kurang dalam memahami konsep-konsep dasar. Lebih daripada itu dilaporkan juga terdapat $8 \%$ partisipan dari seluruh dunia yang kemampuan berpikirnya pada level 5 dan 6 yakni siswa yang mampu dalam menyelesaikan pemecahan masalah serta memiliki kemapuan berpikir kritis yang dinilai baik, dari mereka yang sedikit ini $(8 \%)$ ternyata hanya $0.8 \%$ yang diisi dari siswa Indonesia (Pontianakpos, 11 Desember 2016).

Rendahnya kemampuan berpikir kritis dan hasil belajar siswa Indonesia ini juga didukung dari hasil observasi yang dilakukan peneliti dengan guru Matematika SMP Negeri 1 Indralaya Selatan, bahwa pada materi barisan dan deret siswa masih belum mampu memberikan kesimpulan terhadap materi tersebut yang didukung melalui minimnya siswa dalam menyampaikan gagasan dan mencari informasi. Hal ini ditunjukkan dengan kebingungan siswa saat diminta menjelaskan permasalahan yang diberikan. Mengingat pentingnya materi barisan dan deret pada kurikulum KTSP karena masuk ke dalam salah satu level kognitif penalaran Kisi-kisi Ujian Nasional SMP tahun 2016/2017 yaitu 'Siswa mampu menjelaskan, membedakan, menafsirkan dan menyimpulkan yang berkaitan dengan barisan dan deret' dengan Standar Kompetensi (5) Memahami barisan dan deret bilangan serta penggunaanya dalam pemecahan masalah. Berdasarkan rendahnya kemampuan berpikir kritis siswa dan pentingnya materi barisan dan deret tersebut maka guru mengungkapkan bahwa akan lebih mudah menggunakan metode konvensional pada saat pembelajaran karena mudah menanamkan konsep sehingga waktu pembelajaran menjadi efisien dan target yang ditetapkan tercapai dengan baik. Berdasarkan hasil obeservasi diatas, diduga salah satu yang menjadi penyebab dari rendahnya kemampuan berpikir kritis siswa pada pembelajaran matematika adalah pada pendekatan pembelajaran yang digunakan oleh guru.

Berdasarkan (Zaura \& Sulastri, 2012), salah satu penyebab rendah hasil belajar pada materi barisan dan daret adalah siswa masih sulit dalam memahami konsep dan sulit menerapkan rumus yang terlihat abstrak. Untuk mengatasi masalah tersebut maka diperlukan pembelajaran yang mampu menarik serta membangkitkan semangat siswa 
untuk belajar, semakin tinggi ketertarikan siswa untuk belajar akan meningkatkan aktivitas siswa dalam pembelajaran matematika dan semakin banyak pula yang akan siswa pahami (Nurhidayah \& Sari, 2014) sehingga dapat meningkatkan kemampuan berpikir kritis siswa. Salah satu penggunaan pembelajaran yang tepat adalah pendekatan pembelajaran PMRI (Pendidikan Matematika Realistik Indonesia) karena pembelajaran dengan pendekatan PMRI dimunculkan dengan masalah realistik yang dekat dengan anak, sehingga pembelajaran menjadi lebih bermakna (Widodo, 2014).

Dengan pendekatan PMRI siswa dilatih untuk terbiasa berpikir, berani mengemukakan pendapat dan bekerjasama sehingga mereka dapat menemukan sendiri konsep yang ada dan pada akhirnya siswa menggunakan matematika itu untuk menyelesaikan masalah baik secara individu maupun kelompok (Sofnidar, Sabil, \& Winarni, 2013).

\section{METODE PENELITIAN}

\section{A. Tempat dan Waktu Penelitian}

Penelitian dilaksanakan pada semester genap tahun pelajaran 2016/2017 di kelas IX SMP Negeri 1 Indralaya Selatan.

\section{B. Subjek Penelitian}

Subjek dalam penelitian ini adalah siswa kelas IX.2 SMP Negeri 1 Indralaya Selatan.

\section{Definisi Operasional Variabel Penelitian}

Kemampuan berpikir kritis adalah kemampuan untuk memproses dan mengevaluasi serta menggunakan informasi untuk mencari solusi yang logis. Kemampuan tersebut dinilai dengan skor yang diperoleh siswa melalui soal tes dan penilaiannnya yang mengacu pada indikator kemampuan berpikir kritis, yakni interpretation, analysis, evaluation, dan inference.

1. Interpretation :Memahami masalah yang ditunjukkan dengan menulis diketahui maupun yang ditanyakan soal dengan tepat.

2. Analysis :Mengidentifikasi hubungan-hubungan antara pernyataan-pernyataan, pertanyaan- pertanyaan, dan konsep-konsep yang diberikan dalam soal yang ditunjukkan dengan membuat model matematika dan menulis rumus untuk menyelesaikan soal dengan benar.

3. Evaluation :Menggunakan strategi yang tepat dalam menyelesaikan soal, lengkap dan benar dalam melakukan perhitungan.

4. Inference :Membuat kesimpulan dengan tepat.

5. 


\section{Teknik Pengumpulan Data}

1. Tes

Tes yang digunakan mengacu pada indikator berpikir kritis matematis, yaitu Interpretasi, Analisis, Evaluasi, dan Inference. Soal tes yang telah dikerjakan siswa diperiksa sesuai dengan pedoman penskoran yang telah dibuat. Skor yang didapat siswa untuk setiap soal dijumlahkan, sehingga total keseluruhan skor yang didapat siswa adalah 13. Berikut soal tes yang digunakan:

SOAL TES
1. Erwin ingin membeli Smartphone seharga $3.000,000$ rupiah, sedangkan uang yang
Erwin miliki hanya 2.850 .000 rupiah. Temyata, Smartphone yang ingin Erwin beli
harga jualnya selalu turun 10.000 rupiah per-minggunya. Pada minggu ke
berapakah akhirnya Erwin dapat membeli Smartphone tersebut? Jelaskan dan
tuliskan alasanmu?
2. Bimo dikontrak untuk bekerja di suatu perusahaan selama 10 hari. Sebelum bekerja.
dia diminta untuk memilih antara diberi gaji sebesar 150.000 rupiah perhari selama
10 hari, atau diberi gaji pada hari pertama 5.000 rupiah dan menjadi 2 kali lipat dari
hari sebelumnya selama 10 hari. Mana pilihan terbaik yang harus Bimo pilih agar
mendapat gaji yang maksimal? Berikan alasanmu!

2. Observasi

Observasi digunakan untuk melihat dan menilai keterlaksanaan PMRI pada saat kegiatan belajar mengajar berlangsung.

3. Dokumentasi (Foto dan Video)

Selain observasi, foto dan video pada saat pelaksanaan pembelajaran akan digunakan untuk menunjang data hasil observasi dan data hasil tes.

4. Wawancara

Dalam penelitian ini, wawancara digunakan untuk mendukung hasil tes kemampuan berpikir kritis siswa pada soal barisan dan deret menggunakan pendekatan PMRI. Pada penelitian ini peneliti menggunakan wawancara bebas (tak berstruktur), dimana peneliti tidak memerlukan pedoman wawancara dan siswa dapat dengan bebas memberi tanggapan atas pertanyaaan yang diberikan dari peneliti (Sugiyono, 2008). Subjek yang dipilih berdasarkan kategori kemampuan siswa setelah mengerjakan soal tes. 


\section{Teknik Analisis Data}

1. Data Tes

Setelah dilakukan tes untuk mengukur kemampuan berpikir kritis siswa didapatlah skor untuk masing-masing siswa. Skor tersebut dijumlahkan dan kemudian dianalisis, berikut cara menganalisisnya. Skor yang telah diperoleh dikonversi menjadi nilai dalam rentang 0-100 menggunakan aturan sebagai berikut :

$$
\text { nilai }=\frac{\text { jumlah skor yang diperoleh }}{\text { skor maksimal }} \times 100
$$

(Sumber: Sudjana, Tahun: 2006)

Tabel 1. Kategori Kemampuan Berpikir Kritis Siswa

\begin{tabular}{cc}
\hline Nilai & Kategori \\
\hline $\mathbf{8 0 - 1 0 0}$ & Sangat baik \\
$\mathbf{6 6 - 7 9 , 9}$ & Baik \\
$\mathbf{5 6 - 6 5 , 9}$ & Cukup \\
$40-55,9$ & Kurang \\
$\mathbf{0 - 3 9 , 9}$ & Sangat kurang \\
\hline
\end{tabular}

(Sumber: Arikunto, Tahun: 2013)

\section{Analisis Data Kualitatif}

Dalam penelitian ini peneliti menggunakan analisis data deskriptif kualitatif. Berdasarkan Arikunto (2010) bahwa data kualitatif berguna untuk melengkapi dan menunjang gambaran yang diperoleh dari hasil analisis data kuantitatif (dalam penelitian ini adalah Data tes). Berikut data kualitatif yang digunakan peneliti, data observasi, dokumentasi, dan wawancara.

\section{HASIL DAN PEMBAHASAN}

Kemapuan berpikir kritis siswa diukur berdasarkan hasil jawaban siswa pada soal tes. Hal ini sejalan dengan pendapat Lalang, dkk (2017) bahwa jawaban siswa terhadap soal essay dapat menilai kemampuan berpikir kritis, begitu pula pendapat Fahinu, dkk yang mengatakan kemampuan berpikir kritis siswa dapat dilihat dari kemampuan siswa dalam menjawab soal dengan lengkap dan sistematis. Adapun kategori kemampuan berpikir kritis siswa kelas IX.2 adalah sebagai berikut: 
Histogram: Jurnal Pendidikan Matematika, Volume 1 Nomor 2, Maret 2017, pp 61-75

Tabel. 2. Distribusi Frekuensi Kemampuan Berpikir Kritis Siswa

\begin{tabular}{cccc}
\hline \multirow{2}{*}{ Nilai } & \multirow{2}{*}{ Kategori } & \multicolumn{2}{c}{ Kemampuan berpikir kritis siswa } \\
\cline { 3 - 4 } & & Frekuensi & $\%$ \\
\hline $\mathbf{8 0 - 1 0 0}$ & Sangat Baik & 6 & $24 \%$ \\
\hline $\mathbf{6 6 - 7 9 , 9}$ & Baik & 7 & $28 \%$ \\
\hline $\mathbf{5 6 - 6 5 , 9}$ & Cukup & 3 & $12 \%$ \\
\hline $\mathbf{4 0 - 5 5 , 9}$ & Kurang & 9 & $36 \%$ \\
\hline $\mathbf{0 - 3 9 , 9}$ & Sangat Kurang & 0 & $0 \%$ \\
\hline Total & & & $\mathbf{1 0 0 \%}$ \\
\hline
\end{tabular}

(Sumber: Data Primer, Tahun: 2017)

Dengan presentase setiap indikator kemampuan berpikir kritis sebagai berikut:

Tabel 3. Presentase Kemunculan Indikator Kemampuan Berpikir Kritis Siswa

\begin{tabular}{ccc}
\hline No & Indikator & Presentase \\
\hline $\mathbf{1}$ & Interpretasi & $92,67 \%$ \\
$\mathbf{2}$ & Analisis & $82,00 \%$ \\
$\mathbf{3}$ & Evaluasi & $45,00 \%$ \\
$\mathbf{4}$ & Inference & $44,67 \%$ \\
\hline
\end{tabular}

(Sumber: Data Primer, Tahun: 2017)

Terlihat bahwa presentase kemunculan indikator paling tinggi adalah indikator interpretasi yaitu sebesar $92,67 \%$. Sementara kemunculan indikator paling rendah adalah indikator inference ialah sebesar $44,67 \%$.

Dari hasil analisis data tes kemampuan berpikir kritis siswa, terlihat ada 6 orang siswa atau $24 \%$ yang memiliki kemampuan berpikir kritis kategori sangat baik. Peneliti menganalisis lembar jawaban NA sebagai salah satu siswa yang memiliki kemampuan berpikir kritis. Berkategori sangat baik. Adapun gambaran kemampuan berpikir kritis siswa NA berdasarkan hasil tes dan wawancara adalah sebagai berikut

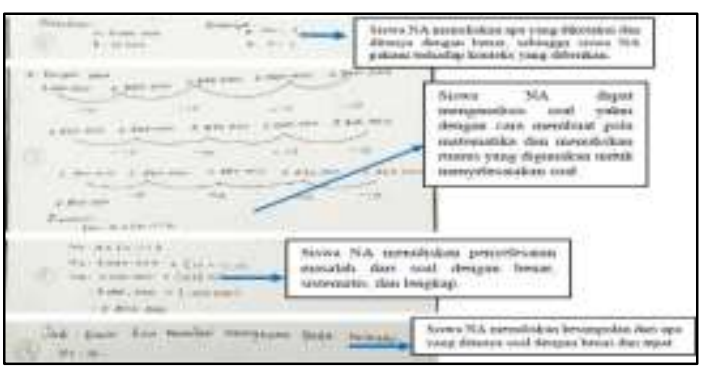

Gambar 1. Lembar Jawaban NA Soal Tes Nomor 1 
Dari lembar jawaban NA siswa paham terhadap konteks soal yang diberikan. Hal ini ditunjukkan dengan NA mampu menuliskan apa yang diketahui dan ditanyakan dari soal dengan benar, sehingga siswa NA memperoleh skor 3 pada indikator interpretasi. Kemudian, pada langkah pengerjaan selanjutnya siswa NA memperoleh skor 3 untuk indikator analisis karena siswa sudah bisa membuat pola dari permasalahan dan dapat menuliskan rumus untuk menyelesaikan soal dengan benar. Setelah itu siswa NA menyelesaiakan masalah soal nomor 1 dengan cara membuktikan hasil jawabannya dengan memasukkan nilai kedalam rumus, pada langkah pengerjaan ini siswa memperoleh skor 4 karena dapat menuliskan penyelesaian masalah dari soal dengan benar, sistematis, dan lengkap. Lalu pada indikator inference, NA memperoleh skor 3 karena kesimpulan yang NA buat sesuai dari apa yang ditanyakan soal.

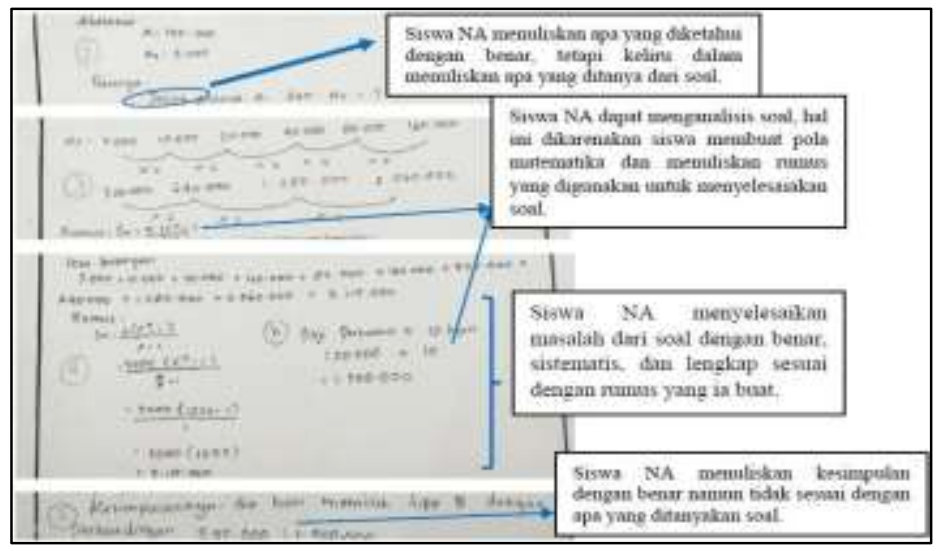

Gambar 2. Lembar Jawaban NA Soal Tes Nomor 2

Pada lembar jawaban soal nomor 2, siswa NA mendapatkan skor 2 pada indikator interpretasi, hal ini disebabkan karena siswa NA keliru dalam menulis apa yang ditanya dari soal Kemudian, siswa NA mendapatkan skor 3 untuk indikator analisis karena siswa sudah bisa membuat pola dari permasalahan dan dapat menuliskan rumus untuk menyelesaikan soal dengan benar. Setelah itu siswa NA menyelesaiakan masalah soal nomor 2 dengan benar, sistematis, dan lengkap berdasarkan rumus yang ia buat, sehingga skor yang ia dapatkan untuk indikator evaluasi adalah 4. Lalu pada indikator inference, NA memperoleh skor 2 karena kesimpulan yang NA buat benar namun belum sesuai dari apa yang ditanyakan soal, hal ini disebabkan karena siswa NA keliru dalam menulis apa yang ditanya dari soal.

Dari hasil analisis lembar jawaban soal nomor 1 dan soal nomor 2, berikut wawancara strategi siswa NA dalam menyelesaikan soal. 


\section{Soal nomor 1}

$P \quad:$ Bagaimana strategi NA dalam menyelesaikan soal nomor 1 ?

NA : Kan di sini saya sudah tahu ini (sambil menunjukkan soal nomor 1) adalah permasalahan dari soal barisan aritmatika dengan rumusnya adalah $U_{n}=a+(n-1) b$.

$P$ : Bagaimana NA bisa tahu soal nomor 1 ini menggunakan rumus barisan aritmatika?

NA : Karena kan di sini lihat soalnya 3 juta adalah harga semula berarti ini adalah a sedangkan ini berkurang. Barisan aritmatika itu selalu berkurang atau bertambah.

$P \quad:$ Tahu barisan aritmatika rumusnya seperti ini dari mana?

$N A$ : Ini kan di pelajaran buat kelompok, nah dari sana kami bisa menentukan rumus barisan aritmatika itu seperti ini. Sebelumnya kan kami belajar pola, ternyata dari pola bisa pake rumus (sambil menunjukkan rumus yang di gunakan)

$P \quad:$ Oh waktu mengerjakan soal LKS?

NA : Iya

$P \quad:$ Nah, waktu mengerjakan LKS kemarin, apakah semua anggota kelompok NA ikut mengerjakan?

NA : Ada sebagian yang bantu nulis dan menghitung, tapi saya buk yang tahu $\underline{\text { idenya }}$

Berdasarkan gambaran hasil analisis tes kemampuan berpikir kritis siswa dan wawancara di atas, maka diperoleh siswa NA dengan kategori kemampuan berpikir kritis "sangat baik", pada lembar jawabannya siswa NA dapat menuliskan penyelesaian soal secara tepat dan sistematis (soal nomor 1). Peran PMRI dengan menggunakan konteks yang nyata dapat membantu siswa NA dalam memahami permasalahan soal dan mentransformasikannya ke bentuk model of situation lalu mengembangkannya ke model for situasion sehingga siswa NA dapat menemukan solusi yang logis dalam menyelesaikan soal. Hal ini sejalan dengan (Rahmawati, 2013) yang mengatakan bahwa dengan adanya masalah kontekstual sebagai titik awal, mampu menjadikan siswa mengkonstruksi pengetahuannya melalui pembuatan model matematika sehingga siswa menemukan sendiri konsep ataupun prosedur matematika.

Selain itu saat proses pembelajaran dengan pendekatan PMRI, siswa NA juga terlibat aktif dalam mengembangkan model matematika pada langkah-langkah penyelesaian LKS. Sesuai dengan (Jaya dan Sutarto, 2012) mengatakan bahwa siswa yang benar-benar melakukan kegiatan pembelajaran dengan aktif dapat membantu siswa untuk lebih memahami materi yang sedang dipelajari. Hal ini juga didukung dengan hasil wawancara, siswa NA mengatakan bahwa ide 
penyelesaian permasalahan di LKS kemarin secara keseluruhan berasal dari siswa NA itu sendiri tanpa bantuan teman kelompoknya.

\section{Soal nomor 2}

$P \quad:$ Pada saat soal nomor 2 bagaimana strategi NA menyelesaikannya?

NA : Disinikan adalah pilihan gaji buk. Inikan soalnya (siswa membaca soal nomor 2). Ini kan di tanya mana pilihan terbaik yang harus di pilih bimo agar mendapat gaji yang maksimal. Di sini, kita tahu bahwa pilihan gaji pertama (gaji tipe pertama) 150 jadi 150 langsung saya kalikan 10 yaitu hasilnya adalah sejuta lima ratus, sedangkan gaji yang kedua yaitu Rp. 5000,00 say gunakan pola yang saya klikan 2 semua dulu (sambil menunjuk pola yang di buat) bisa di gunakan rumus

$$
S_{n}=\frac{a\left(r^{n}-1\right)}{r-1}
$$

$P$ : Nah tadi kan NA bilang yang di tanya itu pilihan gaji terbaik, kenapa disini menuliskan selisih antara pilihan gaji pertama dan gaji kedua?

NA : Ini kan pilihan gaji pertama dan kedua harus di bandingkan yang mana lebih besar.

$P \quad$ : Oh jadi maksud NA kemarin ngebandingkan yang mana yang paling besar, jadi di tulislah seperti perbandingan ini ?

NA : Iya.

Dari wawancara di atas penyebab kesalahan siswa mengerjakan soal nomor 2 adalah siswa salah persepsi atas apa yang ditanyakan soal. Persepsi sendiri menurut Slameto (Kautsar dan Yuniar) adalah proses masuknya pesan atau informasi ke dalam otak manusia. Salah persepsi mengakibatkan siswa salah menafsirkan apa yang dimaksud dari soal sehingga siswa salah dalam melaksanakan rencana penyelesaian masalah. Hal ini berkaitan dengan pendapat (Lestari, dkk: 2016) salah menafsirkan merupakan kesalahan prinsip yang mana adalah kesalahan siswa dalam memahami hubungan fakta dengan konsep yang dikaitkan oleh operasi atau relasi, sehingga siswa tidak dapat merencanakan penyelesaian masalah dengan baik.

Kemudian siswa dengan hasil analisis tes kemampuan berpikir kritis berkategori "baik" terdapat 7 orang atau 28\%. Peneliti menganalisis lembar jawaban HS sebagai salah satu dari siswa yang berkategori baik. Berikut gambaran kemampuan berpikir kritis siswa HS berdasarkan hasil tes dan wawancara. 
Histogram: Jurnal Pendidikan Matematika, Volume 1 Nomor 2, Maret 2017, pp 61-75

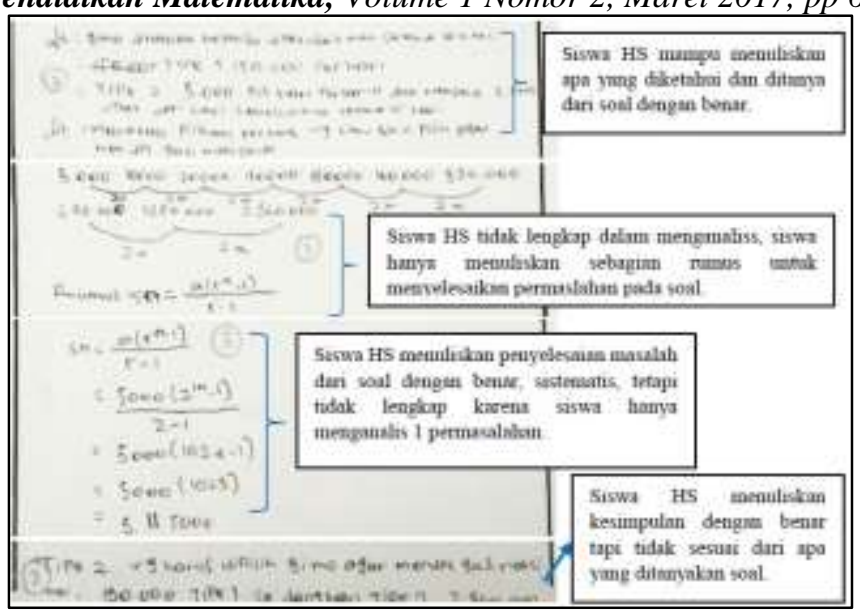

Gambar 3. Lembar Jawaban HS Soal Tes Nomor 2

Lembar jawaban siswa HS, siswa paham terhadap konteks soal yang diberikan. Hal ini ditunjukkan dengan HS mampu menuliskan apa yang diketahui dan ditanyakan dari soal dengan benar, sehingga siswa HS memperoleh skor 3 pada indikator interpretasi. Kemudian, pada langkah pengerjaan selanjutnya siswa HS memperoleh skor 2 untuk indikator analisis karena siswa HS sudah bisa membuat pola dari permasalahan dan dapat menuliskan rumus untuk menyelesaikan soal, namun siswa HS tidak menganalisis semua pilihan dari soal. Setelah itu siswa HS menyelesaiakan masalah soal nomor 2 dengan menggunakan rumus deret geometri, pada langkah pengerjaan ini siswa memperoleh skor 3 karena siswa menuliskan penyelesaian masalah dari soal dengan benar, sistematis, tetapi tidak lengkap. Lalu pada indikator inference, HS memperoleh skor 2 karena kesimpulan yang HS buat benar tapi tidak sesuai dari apa yang ditanya dari soal. Nilai keseluruhan kemampuan berpikir kritis yang diperoleh HS dari soal tes adalah 76,92.

Dari hasil analisis lembar jawaban soal tes kemampuan berpikir kritis soal nomor 2, berikut wawancara alasan siswa HS dalam mampu mengerjakan soal tes dengan baik.

$\mathrm{P}$ : Nah selama pembelajaran pake LKS kemarin, saat mengerjakan apa semua anggota HS ikut mengerjakan?

HS : Dak buk, Cuma aku dan DM, yang lain Cuma ngobrol bae. Jadi aku paham ini gara-gara ngerjakan LKS.

Dari wawancara peneliti dengan siswa HS diatas diketahui bahwa siswa mampu mengerjakan soal tes dengan baik dikarenakan pada saat pembelajaran pendekatan PMRI siswa terlibat aktif dalam mengerjakan kegiatan LKS sehingga siswa paham terhadap permasalahan soal tes. Hal ini menunjukkan bahwa LKS sangat berperan dalam meningkatkan kemampuan pemahaman materi siswa dan didukung juga dengan salah satu fungsi dari LKS menurut Prastowo (Rahmadani, dkk: 2012) yaitu LKS merupakan sebagai bahan ajar yang mempermudah siswa untuk memahami materi yang diberikan. 
Namun dalam penelitian ini masih terdapat siswa-siswa dengan kemampuan berpikir kritis berkategori "cukup" dan "kurang". Terdapat 3 orang siswa atau 12\% yang memiliki kemampuan berpikir kritis berkategori "cukup", salah satunya yaitu siswa TRU. Peneliti menganalisis lembar jawaban TRU sebagai salah satu dari siswa yang berkategori cukup. Berikut gambaran kemampuan berpikir kritis siswa TRU berdasarkan hasil tes.

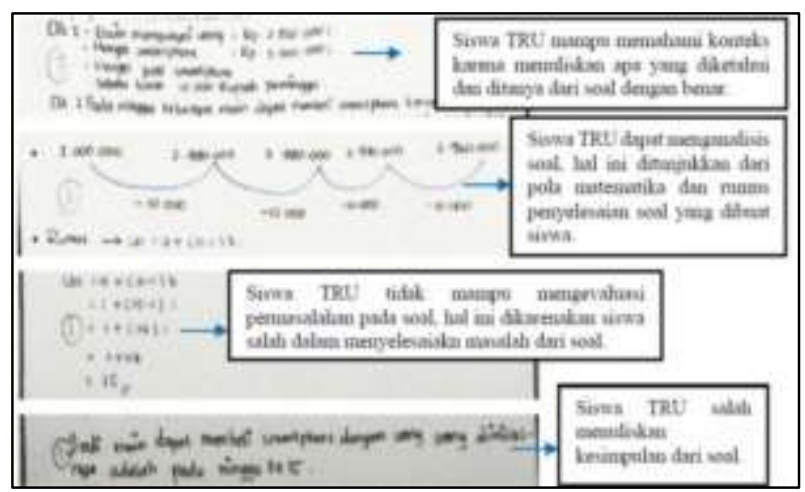

Gambar 4. Lembar Jawaban TRU Soal Tes Nomor 1

Pada lembar jawaban TRU soal nomor 1, siswa mampu memahami konteks dari soal, terlihat dari TRU menuliskan apa yang diketahui dan ditanya dari soal dengan benar sehingga pada indikator interpretasi siswa TRU mendapatkan skor 3. Kemudian saat siswa membuat pola matematika dan rumus untuk menyelesaikan soal, siswa mendapatkan skor 3 karena mampu menganalisis cara menyelesaikan permasalahan dari soal. Walaupun rumus yang ditulis TRU benar, namun pada indikator evaluasi TRU hanya mendapatkan skor 1, hal ini disebabkan karena siswa TRU salah menuliskan penyelesaian masalah dari soal sehingga mengakibatkan siswa TRU salah dalam menuliskan kesimpulan dari apa yang ditanya pada soal dan hanya mendapatkan skor 1 untuk indikator inference. Berdasarkan hasil tes kemampuan berpikir kritis, siswa TRU memperoleh nilai keseluruhan sebesar 57,69.

Dari hasil analisis lembar jawaban soal tes kemampuan berpikir kritis soal nomor 1 siswa TRU, berikut wawancara siswa dalam menyelesaikan soal.

P $\quad$ : Tiara tidak bilang seperti pada saat LKS kemarin, berarti saat mengerjakan LKS kemarin apakah TRU ikut mengerjakan LKS nya?

TRU : Bantu nulis dan ngitung

$\mathrm{P} \quad$ : Nah ide untuk mengerjakan LKS nya itu dari TRU sendiri apa kawan lain?

TRU : Kawan aku buk NA

Dari wawancara di atas dapat dikatakan bahwa siswa TRU masih terbilang pasif pada saat proses pembelajaran dikarenakan siswa TRU belum bisa menuangkan ideidenya dalam menyelesaiakan permasalahan LKS, ide pengerjaan untuk menyelesaiakan LKS lebih didominasi oleh salah satu teman dalam satu kelompoknya yang pintar dan 
memiliki kemampuan berpikir kritis yang tinggi. Hal tersebut sejalan dengan (Munaka, 2009) yang mengatakan bahwa pengerjaan LKS lebih didominasi siswa yang pintar dan mengakibatkan siwa yang lainnya tidak berperan aktif, sehingga siswa yang tidak berperan aktif tadi tidak terbiasa dalam mengevaluasi jawaban.

Siswa dengan kemampuan berpikir kritis "kurang", masih terdapat 9 orang siswa atau 36\%. Peneliti menganalisis lembar jawaban CS dan MRS sebagai perwakilan dari siswa yang berkategori kurang. Berikut gambaran kemampuan berpikir kritis siswa CS dan MRS berdasarkan hasil tes.

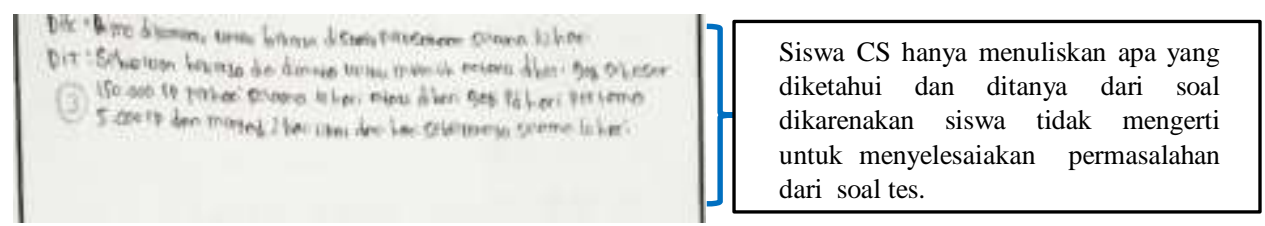

Gambar 5. Lembar Jawaban CS Soal Tes Nomor 2

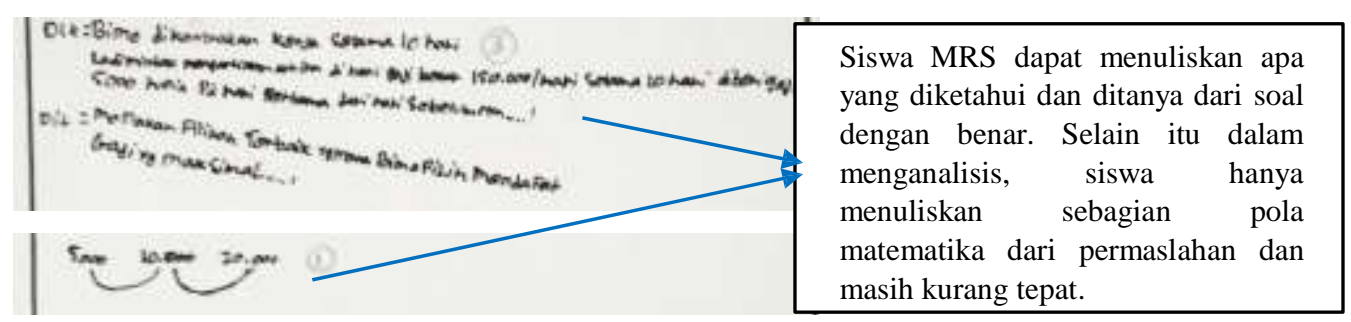

Gambar 6. Lembar Jawaban MRS Soal Tes Nomor 2

Terlihat dari lembar jawaban CS dan MRS pada soal nomor 2 bahwa siswa hanya mampu menyelesaikan soal pada tahap indikator interpretasi, yakni siswa hanya mampu menuliskan apa yang diketahui dan ditanya dari soal, skor yang mereka dapatkan pada indikator ini adalah 3. Sedangkan pada indikator analisis, siswa MRS memperoleh skor 1 karena siswa hanya menuliskan sebagian pola matematika dan masih kurang tepat. Kemudian pada indikator evaluasi dan indikator inference siswa CS dan MRS tidak menuliskan sama sekali sehingga siswa diberikan skor 0 untuk dua indikator tersebut. Berdasarkan hasil tes kemampuan berpikir kritis, siswa CS dan MRS memperoleh nilai keseluruhan sebesar 46.15 .

Dari hasil analisis lembar jawaban soal tes kemampuan berpikir kritis soal nomor 2 siswa CS dan MRS, berikut wawancara alasan siswa tidak dapat menyelesaikan soal nomor 2 .

\section{Siswa CS}

$\mathrm{P} \quad$ : Pada saat mengerjakan soal nomor 2 tes, kenapa CS hanya menuliskan diketahui dan ditanya dari soal?

CS : Dak tau lagi buk nak ditulis apo. 
P $\quad$ : Kok bisa dak tau lagi, emangnya kemarin selama pembelajaran, CS ikut dak mengerjakan soal $\underline{L K S}$ nyo?

CS : Ikut buk. Nulis-nulisnyo bae buk.

$\mathrm{P} \quad$ : Paham materinya dak?

CS : Dak.

\section{Siswa MRS}

$\mathrm{P} \quad$ : MRS, kenapa penyelesaian nomor 2 kamu hanya bisa menuliskan diketahui dan ditanya?

MRS : Dak tau nak nulis apo lagi buk, waktu lah mau habis.

$\mathrm{P} \quad$ : Kira-kira tau gam au pakai rumus apa untuk menyelesaikan nomor 2 ini?

MRS : Dak tau buk.

$\mathrm{P} \quad$ : Nah waktu mengerjakan LKS berkelompok kemarin apakah MRS ikut menyelesaikan LKS dengan anggota kelompok? atau memang tidak ikut sehingga sampai tidak tau mau pakai rumus apa?

MRS : Tidak ikut buk.

Berdasarkan gambaran hasil analisis tes kemampuan berpikir kritis siswa dan wawancara di atas, CS dan MRS merupakan siswa dengan kemampuan berpikir kritis dengan kategori "kurang" terhadap permasalahan soal tes. Hal ini terlihat dari lembar jawaban soal nomor 2 , siswa CS dan MRS tidak mampu menganalisis permasalahan yang diberikan sehingga siswa tidak dapat menuliskan penyelesaian dan kesimpulan dari soal. Selain itu hasil wawancara menunjukkan bahwa siswa CS tidak berperan aktif selama proses pembelajaran sehingga dia tidak paham terhadap materi yang sedang dibahas saat pembelajaran. Siwa MRS juga mengatakan bahwa MRS memang tidak ikut serta mengerjakan LKS berkelompok sehinga dia tidak paham terhadap materi. Kemudian berdasarkan hasil observasi peneliti selama melaksanakan proses pembelajaran, siswa MRS memang jarang dalam mengemukakan pendapatnya, tidak pernah ikut mengerjakan permasalahan yang ada pada LKS, dan hanya berkeliling kelas untuk melihat apa yang dikerjakan temannya di kelompok lain.

Penyebab siswa-siswa dengan kemampuan "cukup" dan "kurang" di atas pasif selama proses pembelajaran PMRI berlangsung dikarenakan siswa masih belum terbiasa menggunakan pembelajaran dengan pendekatan PMRI yakni pembelajaran yang mengkonstruksi sendiri pengetahuan matematika siswa sehingga siswa kesulitan dalam menghubungkan materi dengan konteks yang telah ditentukan. Menurut (Winarni \& Rohati, 2012) hal tersebut disebabkan karena PMRI adalah hal baru bagi siswa dari kebiasaan cara belajar siswa yang masih menunggu cara penyajian guru atau menunggu teman sebaya yang biasa membantu mengerjakan latihan matematika yang diberikan. 
Histogram: Jurnal Pendidikan Matematika, Volume 1 Nomor 2, Maret 2017, pp 61-75

\section{KESIMPULAN DAN SARAN}

\section{A. Kesimpulan}

Berdasarkan hasil penelitian di kelas IX.2 SMP Negeri 1 Indralaya Selatan, diperoleh hasil bahwa kemampuan berpikir kritis siswa pada materi barisan dan deret setelah melaksanakan pembelajaran dengan pendekatan PMRI berkategori cukup kritis dengan nilai rata-rata 64,46 , rincian presentase sebagai berikut : persentase siswa yang memiliki kemampuan berpikir kritis dengan kategori sangat baik sebanyak 24\%, siswa yang memiliki kemampuan berpikir kritis dengan kategori baik sebanyak 28\%, siswa yang memiliki kemampuan berpikir kritis dengan kategori cukup sebanyak 12\%, dan siswa yang memiliki kemampuan berpikir kritis dengan kategori kurang sebanyak $36 \%$, serta tidak ada siswa yang memiliki kemampuan berpikir kritis dengan kategori sangat kurang. Indikator Interpretasi pada kemampuan berpikir kritis memiliki persentasi kemunculan tertinggi yaitu sebesar 92,67\%, kemudian indikator Analisis pada kemampuan berpikir kritis memiliki persentase kemunculan sebesar 82\%, indikator Evaluasi pada kemampuan berpikir kritis memiliki kemunculan presentase sebesar $45 \%$, dan indikator dengan kemunculan terendah adalah indikator Inference sebesar 44,67\%.

\section{B. SARAN}

Dari hasil penelitian untuk melihat kemampuan berpikir kritis siswa di kelas IX.2 SMP Negeri 1 Indralaya Selatan pada materi barisan dan deret dengan pendekatan PMRI, maka peneliti menyarankan:

1. Bagi siswa, sebaiknya siswa lebih berlatih kemampuan berpikir kritis, khususnya pada indikator Analisis, Evaluasi, dan Inference.

2. Bagi guru, sebaiknya saat pembelajaran dengan pendekatan PMRI lebih menekankan lagi pada salah satu karakteristik PMRI yaitu Interaktivitas agar dapat melatih siswa dalam mengemukakan pendapatnya selama pembelajaran matematika sehingga dapat mengembangkan kemampuan berpikir kritis siswa selama pembelajaran.

3. Bagi peneliti lain, penelitian pembelajaran dengan menggunakan pendekatan PMRI dapat digunakan untuk melihat kemampuan lainnya.

\section{DAFTAR PUSTAKA}

Arikunto, S. (2013). Dasar-Dasar Evaluasi Pendidikan (Edisi 2). Jakarta: PT. Bumi Aksara.

Jaya, B. D., \& Sutarto. (2012). Metode Eksperimen Terbimbing dalam Pembelajaran Fisika di SMP. Jurnal Pembelajaran Fisika. 1(1): 80-86.

Kemendikbud. (2015). Buku Guru Matematika SMP/MTs Kelas IX. Jakarta : Kemendikbud. 
Lambertus. (2009). Pentingnya Melatih Keterampilan Berpikir Kritis dalam Pembelajaran Matematika di SD. Forum Kependidikan. 28 (2): 136-142.

Muhfahroyin. (2009). Memberdayakan Kemampuan Berpikir Kritis Siswa Melalui Pembelajaran Konstruktivistik. Jurnal Pendidikan dan Pembelajaran. 16 (1): 88-93.

Munaka, F., Zulkardi, \& Purwoko. (2009). Meningkatkan Kemampuan Siswa Menyelesaikan Soal Kontekstual Melalui Cooperative Learning di Kelas VIII1 SMP Negeri 2 Pedamaran OKI. Jurnal Pendidikan Matematika. 3(9): 47-60.

Winarni, S., \& Rohati. (2012). Pengembangan Bahan Ajar Materi Sistem Persamaan Linear Dua Variabel dengan Menggunakan Pendekatan Pendidikan Matematika Realistik Indonesia (PMRI) di SMP. Edumatica. 2(2): 43-50.

Zaura, B., \& Sulastri. (2012). Model Pembelajaran kooperatif Tipe STAD sebagai Upaya Meningkatkan Hasil Belajar Siswa pada Materi Barisan dan Deret Bilangan di Kelas IX SMP Negeri 1 Labuhanhaji Aceh Selatan. Jurnal Peluang. 1 (1): 21-29.

Rahmadani, A., Amalita, N., \& Helma. (2012). Penggunaan Lembar Kerja Siswa yang Dilengkapi Mind Map dalam Pembelajaran Matematika. Jurnal Pendidikan Matematika. 1(1): 30-34.

Sofnidar,. Sabil, H., \& Winarni, S. (2013). Penerapan Pendekatan PMRI untuk Meningkatkan Kemampuan Konsep Geometri Mahasiswa PGSD Universitas Jambi. Semirata 2013 FMIPA Unila: 489-504.

Widodo, M.S. (2014). Keefektifan Pembelajaran Matematika dengan Pendekatan Matematika Realistik Indonesia (PMRI) pada Materi Lingkaran di Kelas VIII SMP. MATHEdunesa. 3(3): 125-130.

Somakim. (2011). Peningkatan Kemampuan Berpikir Kritis Matematis Siswa Sekolah Menegah Pertama dengan Penggunaan Pendidikan Matematika Realistik. Forum MIPA. 14 (1): $42-48$.

Lalang, A., Ibnu, \& Sutrisno. (2017). Kemampuan Berpikir Kritis dan Pemahaman Konseptual Siswa dengan Inkuiri Terbimbing Dipadu Pelatihan Metakognisi pada Materi Kelarutan dan Ksp. Jurnal Pendidikan 2(1): 12-21.

Lestari, A. P., Hasbi, M., \& Lefrida, R. (2016). Analisis Kesalahan Kelas IX dalam Menyelesaikan Soal Cerita Keliling dan Luas Lingkaran di SMP Al-Azhar Palu. Jurnal Elektronik Pendidikan Matematika Tadulako. 03(04): 373-385.

Rahmawati, F. (2013). Pengaruh Pendekatan Pendidikan Realistik Matematika dalam Meningkatkan Kemampuan Komunikasi Matematis Siswa Sekolah Dasar. Kumpulan Makalah Seminar Semirata 2013 : 225-238. 